\title{
Dasht-e Lut in Iran, the Most Complete Collection of Beautiful Geomorphological Phenomena of Desert
}

\author{
Abdollah Yazdi ${ }^{*}$, Mohammad Hashem Emami², Seyed Mohsen Shafiee ${ }^{1}$ \\ ${ }^{1}$ Department of Geology, Kahnooj Branch, Islamic Azad University, Kerman, Iran \\ ${ }^{2}$ Department of Geology, Islamshahr Branch, Islamic Azad University, Islamshahr, Iran \\ Email: Yazdi mt@yahoo.com
}

Received 13 March 2014; revised 12 April 2014; accepted 20 April 2014

Copyright (C) 2014 by authors and Scientific Research Publishing Inc.

This work is licensed under the Creative Commons Attribution International License (CC BY). http://creativecommons.org/licenses/by/4.0/

c) (i) Open Access

\section{Abstract}

Given special tectonic and climatic conditions, Iran has the most diverse land-forms and beautiful geological phenomena, which could attract many scientific, adventurous tourists and geological researchers. The present study aims at studying and introducing wonderful geomorphological attractions and numerous geotourism potentials of very hot paradise of the earth, e.g. Dasht-e Lut of Iran, a desert which contains a collection of exclusive desert relieves and geological and geomorphological records of the world. Such unique perspectives as the biggest Nebkhas of the world, the largest Yardangs or Kaluts of the world, the hottest point of the earth, as well as rare species of desert structures such as salt marshes and salt polygons, Gandom Beryan Hill, massive sand dunes, Barchans, clay zones in pretty shapes, saline river, etc., present a vast and diverse extension of geographical beauties and phenomena of the desert. Using library studies, interpretation of satellite images and field studies, this study has been conducted. The results of the studies show that Lut Desert has considerable capability for carrying out complementary studies as well as effect on economic development process in national and international levels. In addition, geotourism development obstacles in Lut Desert are identified, and such solutions as development of ways for access to attractions, erection of geotourism development centers, advertisement and introduction of the desert's attractions, dispatch of guides with tourists, promotion of the region security, extension of accommodations and... for better use of the potentials of the desert, are provided. Furthermore, towards developing the region geotourism, some other fun and exciting activities such as sand skiing, racings and desert rallies, endurance cycling, sun bath, star observation, camel riding and so on, are suggested. Obviously, having various desert attractions and multiple geotourism potentials, Dasht-e Lut has the capability of being considered among global geoparks of UNESCO.

\footnotetext{
${ }^{*}$ Corresponding author.
}

How to cite this paper: Yazdi, A., Emami, M.H. and Shafiee, S.M. (2014) Dasht-e Lut in Iran, the Most Complete Collection of Beautiful Geomorphological Phenomena of Desert. Open Journal of Geology, 4, 249-261. 


\section{Keywords}

\section{Geomorphology, Geotourism, Dasht-e Lut, Deserts, Kalut, Iran}

\section{Introduction}

Iran has rich culture and outstanding landscapes. Its diverse cultural and natural features have ranked Iran among the world's first ten best tourist destinations (F. Frangilli, World Tourism Organization Secretary General, 2004). Iran's archaeological, cultural, natural, and geological attractions contribute to the development of geotourism (Amrikazemi and Mehrpooya, 2006), [1].

Iran is located in the Middle East, Southeast Asia and its geological features were studied by many researchers; it has also been called the "geologists' heaven”(Amrikazemi2009), [2]. Iran has original and appealing geological structures and zones, various climates and diverse geographical features, including high mountain ranges peaks, vast expanses of desert, long rivers, and permanent glaciers.

Desert land forms cover twenty-five percent of Iran's area. These lands include a unique collection of geomorphological phenomena. Dasht-e Lut and Dasht-e Kavir are Iran largest deserts. This paper investigates Dasht-e Lut's geomorphological features and its attractions in detail. The word Lut means barren in a way that lacks everything. In other words, it lacks vegetations and water, two vital factors for the survival of humans and animals; as a result, some indigenous people were and still are afraid to go to this area. Therefore, this wonderful land has still remained somehow unknown to researchers.

\section{Research Method}

This article is applicable and developing one and the used research method is descriptive analytic. According to the variant library studies, interpretation and analysis of satellite images for the studied areas and field studies are used for this purpose.

\section{Geotourism Concept}

Geotourism has a defined boundary that geological tourism is on its center of attraction (Newsome \& Dowling, 2006) [3] and is surveying the complications associated with the ground, geomorphological situation, geostructural phenomena and their tourism capability. From the viewpoint of Gates (2006) [4], geotourism means "tourism in geological landscapes". Moreover, it can be said that geotourism is a responsibly and conscious tourism in the nature with the aim of visiting and recognizing the geological processes and phenomenon as well as learning the way of their forming and evolution (Amrikazemi, 2009), [2]. According to the provided definitions, geotourism is not only a new section in tourism market, but also it is considering a guideline for helping to maintenance the inanimate life and sustainable development. Most of geotourism audiences are not just geologist but also they are friends of nature. Therefore, geotourism tries to make the land visiting targeted via creation and defining geosites (a place that has uncommon shapes and interesting geological and geomorphological processes) and geoparks (a place that has one or several unique geological phenomenon as well as considerable natural and cultural attractions) and prevent the geological heritage via humans.

\section{Dasht-e Lut Location}

Dasht-e Lut in some scientific sources was also called the Lut Hole is located between the latitudes of 28 to 32 degrees N. It has 900 kilometers long from north to south, and it has 200 to 300 kilometers width from west to east. It is 199,000 square kilometers in area, which covers a region surrounded by South Khorasan Province, Sistan va Baluchistan, and Kerman (Figure 1).

Considering the Dasht-e Lut's structural location, it is surrounded by from east by Nehbandan Fault and the flyscharea in the east of Iran, from west by Nayband Fault and the block of Tabas, from north by the graben in the south of Kashmar, and from the south by Jazmoryan's pit in the west of Baluchistan (Stocklin et al., 1973), [5]. This area is massive and prone to earthquakes (Moatamed 1973), [6].

This deep low-lying land which is at least 185 meters below the sea level experienced prevailing and rather 


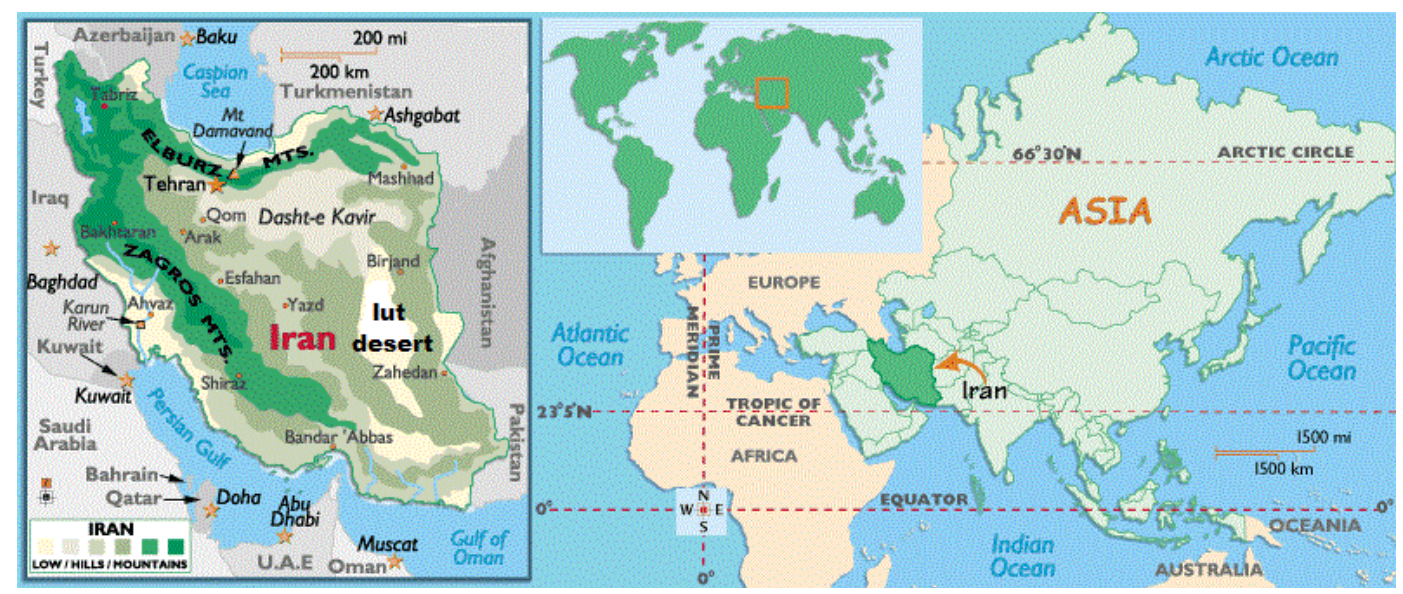

Figure 1. Dasht-e Lut's (lut desert) location in Iran.

strong winds blowing from east to west. These winds took 120 days long during the year called Sistan's onehundred-and-twenty-day winds, play a major role in creating morphological structures across the lut desert (Dasht-e Lut) ( Rahnama Rad and Saheb Zade 2010), [7].

\section{Geology}

Stocklin in 1968 believe that Lut block could be divided in to two parts, Eastern part and western part. Camel mountain range (shotori mountain range) is regarded as the boundary between two parts. The new evaluations revealed that the mentioned parts are completely different from each other considering petrologic properties. In addition, various seismo tectonics movements were seen in two parts that make difference between two parts. Dasht-e-Lut includes volcanic rocks of Tertiary system with approximately $2000 \mathrm{~m}$ thickness. The volcanic rocks cover more than half of Lut block. Lake deposits in the area called Lut formation representing folding of the block (Aghanabati, 2004), [8].

\section{Geographical Position}

This beautiful and varied land is a display of the most wonderful desert-related structural phenomena and features which their study can be of value to geology and geography researchers as well as geotourism lovers. Regarding Dasht-e Lut's geomorphological structures, we can study it into three geographical areas: Northern, Central, and Southern Lut(Ibrahimzade 2009), [9]. they are also called Birjand or Khorasan's Lut, Lut's Central Hole, and Zangi Ahmad Lut respectively (Rounaghi, 2012), [10] (Figure 2).

\subsection{Northern Lut}

The northern part of the Lut is a quite high, vast and triangular plain which three different areas-including Deh Salam, Godar-e baroute, and Mt. Morghab, are located at various points. It may be possible to consider the road from Shahdad city to the Nehbandan as the boundary between Northern and Central Lut. The height of Northern Lut changes from about 600 hundred meters in the southern areas to one thousand meters in the northern and western areas (www.irandesert.com). A large part of Northern Lut is made of scattered volcanic and sedimentary single mountains and hills (Nabavi 1984), [11]. There are not many drifts of sand in this area, and most of the plain is covered with sand and volcanic gravel.

\subsection{Central Lut}

This area is the largest and the most wonderful part of Dasht-e Lut. The northern part of Central Lut is about 600 meters in height which decreases as it stretches to the south. The lowest point of Iran's internal flats is located in the Kaluts' area, being only 185 meters above the average of sea level. There are some scattered mountains in Central Lut which are mainly volcanic and follow a north-to-south pattern. These mountains are located in the northeast part of Central Lut and in the west of Rig-e Yalan. Some scattered mountains can be seen near the 


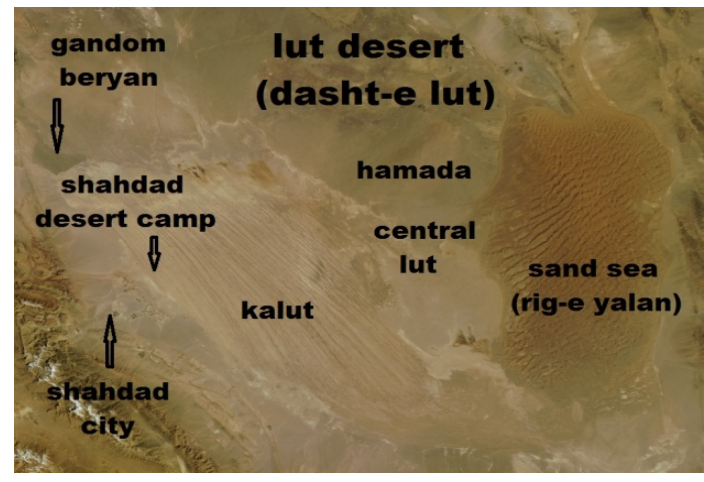

Figure 2. Satellite image of Dasht-e Lut and its notable morphologic parts.

border of Northern and Central Lut. Regarding Central Lut's important geologic structures, we can name Mt. Malek Mohammad in the west of Rig-e Yalan and Mt. Simourgh in the north of Central Lut (Yazdi, 2012), [12].

Thus, we can divide Central Lut into five parts based on its structural appearance:

-There is a massive and tremendous flat plain in the center, which is entirely covered with both volcanic gravel and stone (called Hamada) and gypsum gravel and stone. This area is located between sand dunes in the east and the Kaluts in the west of Lut. Some researchers believe this area lacks life (Figure 3).

There are lands covered with salt and gypsum lands scattered in the central area, Malek Mahmoud Hole in the west of Rig-e Yalan.

-There are clayey lands hosting short life vegetation and mainly exist in the north and south of Lut.

-There are sandy lands in the eastern part also known as Rig-e-Yalan they are scattered between the Kaluts in the west.

-In the west, there are huge dunes of clay which were formed into various beautiful shapes as a result of erosion; they are known as Kalut.

\subsection{Southern Lut}

The southern part of Lut, known as Zangi Ahmad Lut, is an extensive plain which its northern border is a line joining the village of Gorg in the east of Lut to the village of Kashit in the west of Lut. Its southern border is the mountains of Azar located between Bam and the Bam-Zahedan route. This part of Lut mainly includes flat plains.

The vegetation of Southern Lut is magnificent. Except the eastern and western parts of Central Lut, Southern Lut has the highest amount of vegetation of the Lut Hole. The vegetation is mainly seen in the northern, central, western, and southwest areas while the southern and southeast areas have poor vegetation; some large areas even lack vegetation entirely. In these parts, south and southeast, which are almost covered with Hamada, some individual plants can be seen far from each other. In the south of Southern Lut, Dasht-e Bam and Narmashir are located which are comprising the part of the Lut Hole. The surface of this area is covered with scattered sand hills and moving sand (Rounaghi, 2012), [10].

\section{Geotourism Attractions Lut Desert}

The features and the beautiful shapes of the desert will be described in the following, these features and scenes can be a great source of joy and excitement to geotourists.

\subsection{Sand Hills}

In the east of Dasht-e Lut Mt. Sistan and Mt. Khorasan, there are a large number of various sand structures which cover an area of 10,000 square kilometers; the local people call this area Rig-e Yalan. It resembles a rectangle. It is about 150 kilometers long from north to south, and 70 kilometers from east to west. The sand hills vary in height; they sometimes reach 500 meters (Rounaghi, 2012), [10] (Figure 4).

Some researchers believe that these sand pyramids are the biggest in the world, in fact, they are ranked in the 


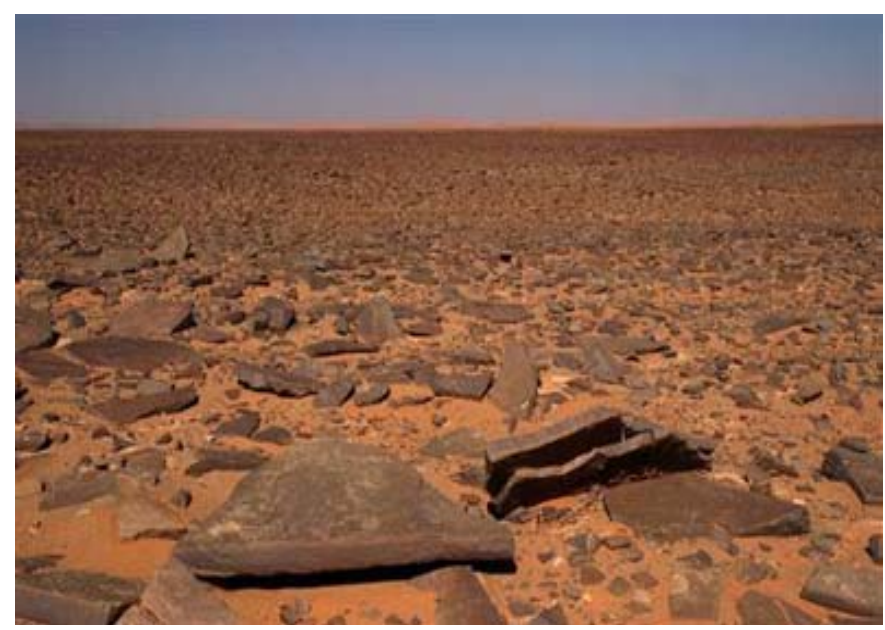

Figure 3. Hamada in Iran's central Lut.

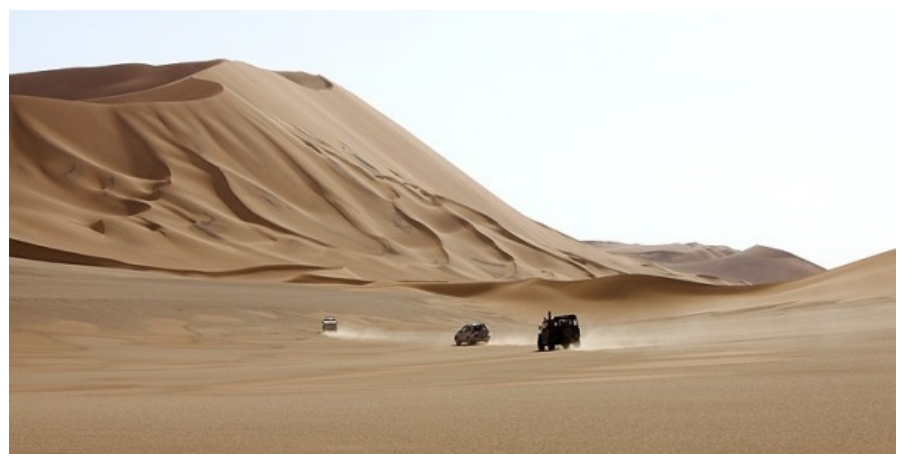

Figure 4. Dasht-e Lut's sand dunes (Rig-e Yalan).

third place since the sand hills of Cerro Blanco-being 1176 meters high—in Peru and the sand hills of BadianJaran — being 550 meters high — in Mongolia are in the first and second place respectively (Yazdi, 2012), [12].

In addition, there are scattered sand hills with different shapes, crescent-shaped hills called Barchan and sword-shaped hills called Seif (Figure 5 \& Figure 6). On the surface of these hills, there are beautiful scenes of ripple marks which are created by the wind. Therefore, in addition to the beautiful scenes of these hills, they make a great place for skiing on sand.

\subsection{Yardang}

In desert areas and especially in soft lands, the soil is drifted which results in the formation of small hills and long elongated furrows called Yardang. These furrows can be seen in the south of Dasht-e Lut (Figure 7).

\subsection{Nebkha}

Dasht-e Lut's special features are the existence of the world's biggest Nebkahs (with regard to the height and vastness) in its west side. In fact, plant traps or Nebkhas are a feature which is mostly created in areas where there are wind-drifted sediments. They are created when sand and gravel are trapped by tamarisk trees; these structures are also called Nebkha's Plan Pot which can be seen at 30 kilometers away far from Shahdad (near the village of Karim Abad). Nebkhas consist of sand, clay, and silt. Nebkhas are usually created in flat areas-with an average level of sand-where the groundwater level is high or there is enough moisture for plants to grow. Sometimes, the Nebkhas in Lut grow ten meters in length, and some of them stretch over an area of 40 meters while the longest Nebkhas in Sahara only grow up to three meters long. Nebkhas go through different stagesfrom their time of creation until they are fully-grown, during their lifetime. It also appears that Lut's Nebkhas can grow fully (Figure 8). 


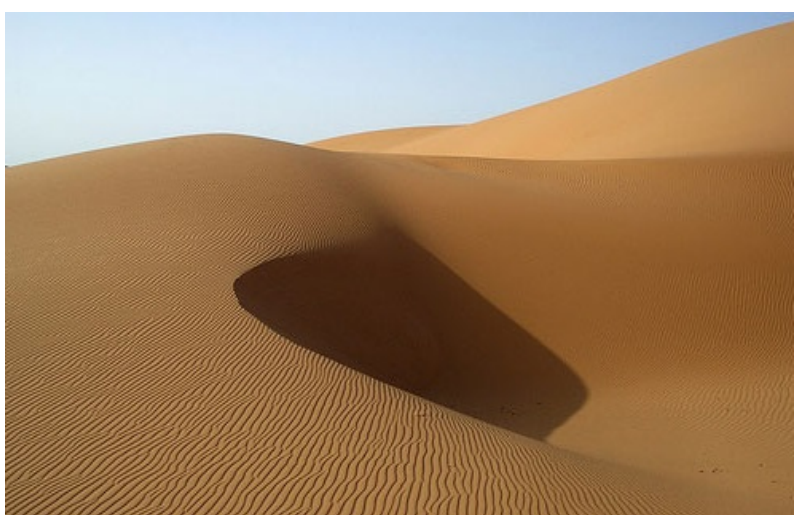

Figure 5. Dasht-e Lut's sand dunes, Barchan and ripple marks.

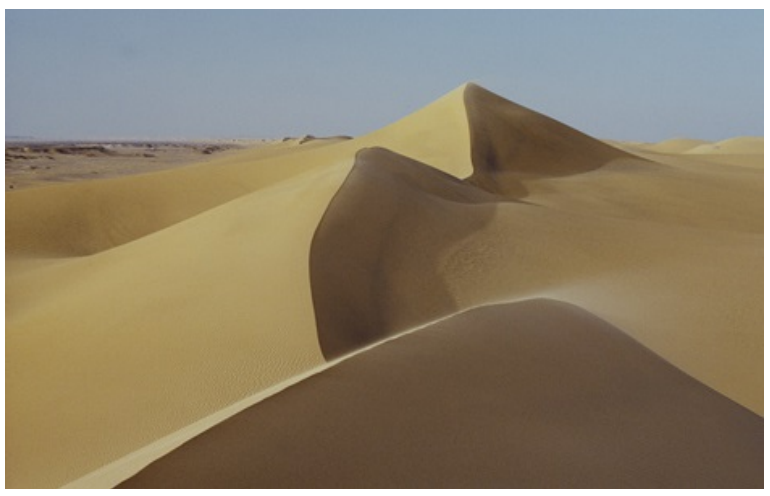

Figure 6. Seif in Rig-e Yalan area.

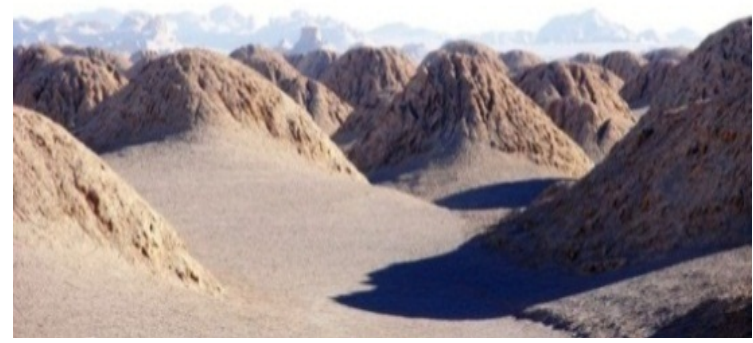

Figure 7. Dasht-e Lut's Yardangs.

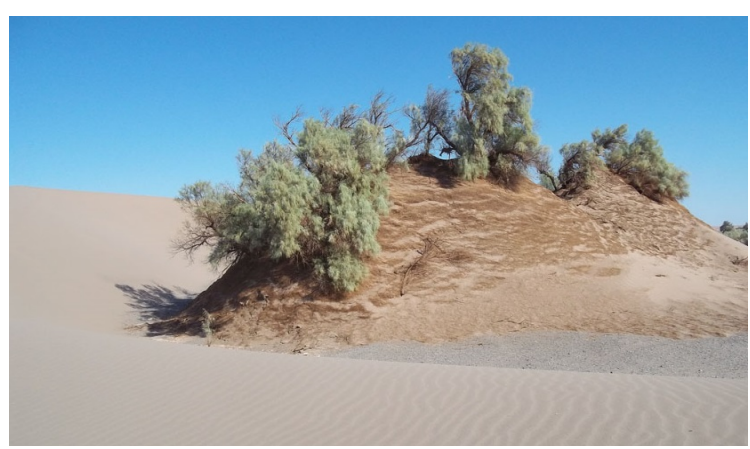

Figure 8. The construction of Nebkahs in Dasht-e Lut. 


\subsection{Rebdou}

Rebdous (large salt pots) differ from Nebkhas considering its larger size. They vary from 2 to 7 meters in length and from 1 to 5 meters in width. Considering their larger size, Rebdous look more complicated, they can sometimes be seen as several contiguous cones. The highest Rebdou can be seen in the west of Lut, with a height of 12 meters.

\subsection{Kalut}

One of the most exciting geomorphological structures of Lut is the special bumps called Kalut which is the biggest natural clod structure in the world; they are the most unique structures in the desert. Kaluts are similar to parallel tunnels which are positioned from northwest to northeast. Kaluts are 80 kilometers in width, 150 kilometers in length, and in some cases 120 meters high; they are located in the west of Central Lut at a distance of 43 kilometers from Shahdad. From a distance, Kaluts look like the ruins of a big legendary city with grand palaces and buildings both short and high. In fact, these Kaluts were created by the wind and rain, and they are very attractive (Moatamed, 1973), [6] (Figure 9 \& Figure 10).

The results of studies have shown that erosion and the drifting of sand from the Kaluts into the holes of Lut's structures were performed periodically (Khosravi, 1998), [13]. In fact, their structures show that erosion caused by either the wind or rain happened simultaneously or in consecutive dry or rainy periods (Rahnama Rad and SahebZadeh, 2011), [14]. Between kaluts, there are salty desert lands similar to polygons or plowed lands-this is due to the high level of groundwater and gypsum. Below the ground surface of these areas-10 to 20 centimeters deeper there are hard layers of different salts: calcium, sodium, and magnesium (Rahnama Rad and SahebZadeh, 2011), [14].

Special guest houses with traditional design were built near the Kaluts so that the traditional and natural structure of the area would not be disturbed.

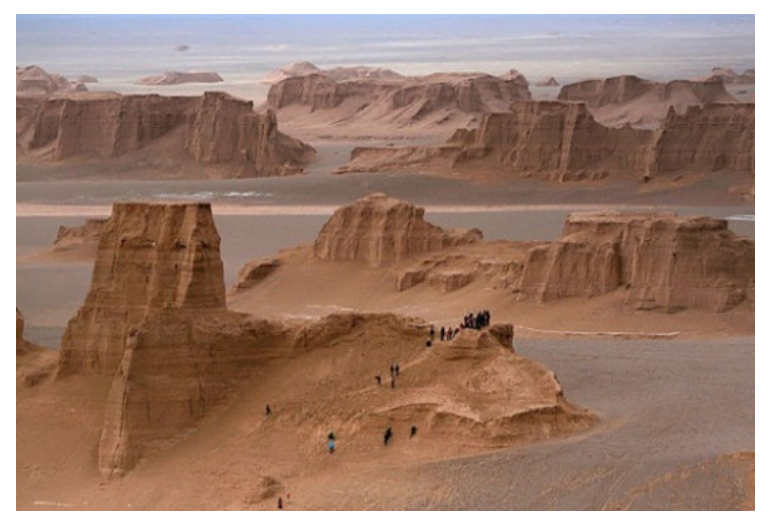

Figure 9. Dasht-e Lut’s Kaluts.

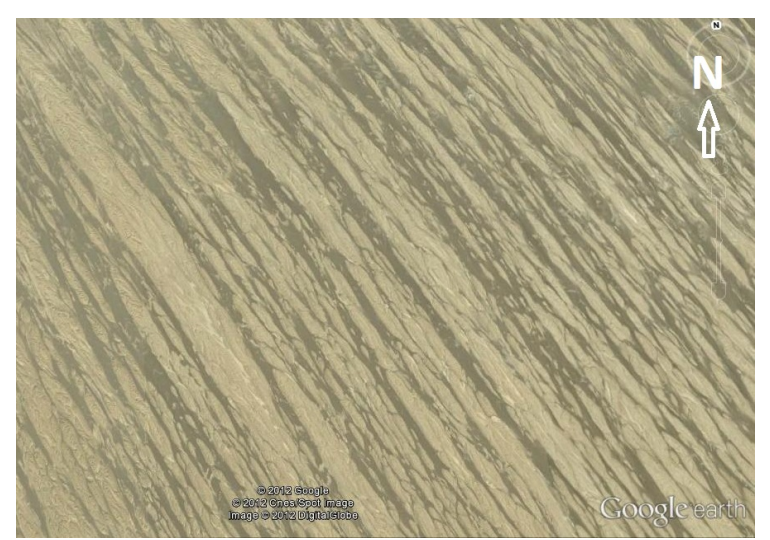

Figure 10. Satellite image of Kaluts. 


\subsection{Camel-Foot Plain (Dasht-e-Pashotori)}

The shapes of the surface of the lands resemble a land which becomes wet after raining, and then some camels walking over the land (Figure 11).

\subsection{Lut Beautiful Salt Lands}

In areas where salt water accumulates or places that are affected by salt groundwater, salt lands of various shapes are formed (Figure 12), which can be classified according to their appearance.

Oval Plains: Egg-shaped forms created in salty ground. The salt on the ground surface is formed into the shape of an egg (an ostrich egg) which is quite unique in the world.

Spring Plains: The area looks like covered with springs while there is no water in the area.

Plowed Plains: These areas look like farm lands which have been plowed (Figure 13).

Stalagmite Salt Lands: The salt on the surface of these areas looks like stalagmite or salt spikes which beautifully appear on the surface of the land.
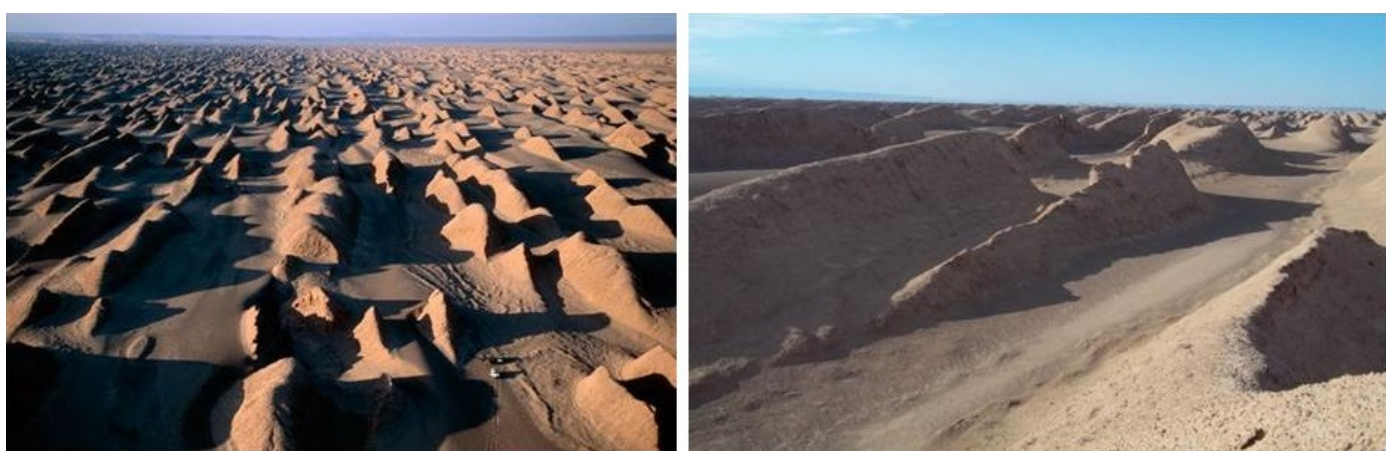

Figure 11. Dasht-e Lut’s camel—foot plain (Dasht-e-pashotori).

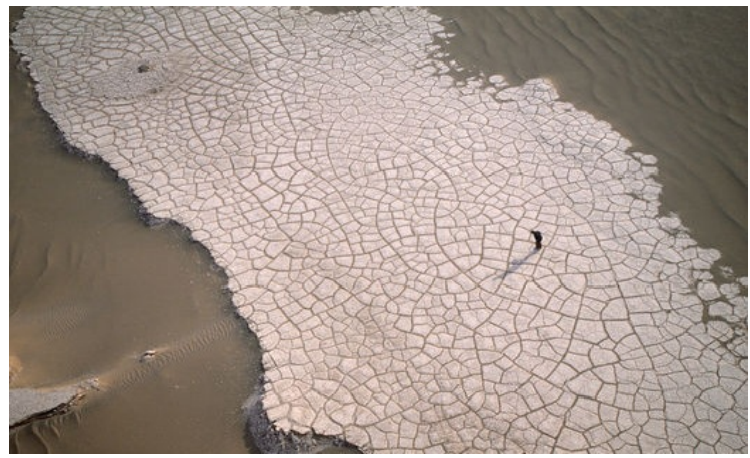

Figure 12. A beautiful image of Dasht-e Lut's salt land.

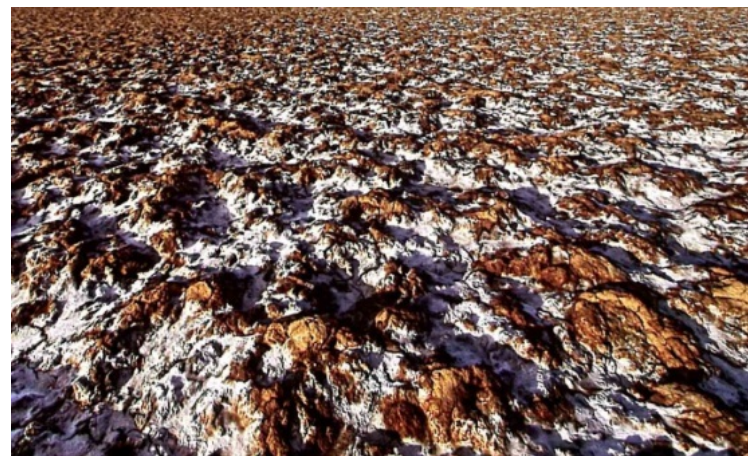

Figure 13. Puffed salt-clay desert land, south lut. 


\subsection{The Hottest Place on Earth}

The theory that Lut is the thermal center of the earth was proposed by Professor Stratil Sauer from the University of Vienna in Austria in 1952. After some aerial analysis, the west part of Nosrat Abad, Rig-e Yalan introduced as the hottest place on earth. Theodore Mono confirmed the mentioned area among the hottest places on earth. According to NASA's maps, the hottest temperature on earth (70.7 centigrade Celsius) was recorded in the lowest area of Lut—an area in the east of Kaluts—in 2005 (Solouti and Babaniavardi 2011), [15]. Likewise, Iranian researchers, including Professor Kardavani and Mahmoudi believe the hottest place of earth is located somewhere in this desert (Kardavani1973), [16] [17]. Due to extreme heat, the best months to visit Dasht-e Lut are from November through February. It borders the cold area of Sirch with cool and pleasant weather, and several water resources.

\subsection{Shoor River}

This River is the only permanent river which runs deeply in Dasht-e Lut and has of water all the year. It origins from the northwest mountains in Birjand, and after flowing through its bendy path in the desert, ends up in the salty mountain and salty mine of Shahdad (Figure 14).

Its water is very salty, and as it moves closer to Lut's Central Hole the amount of its minerals increases due to evaporation and passing through salt land. Its water becomes so salty that no plants can be found for kilometers downstream. In addition, before it reaches the salt mine due to the increased amount of salt, the water of the river became very viscous. This results in some unique scenes around this river (Figure 15 \& Figure 16). Despite the level of droughts in recent years, the river has not stopped flowing.

\subsection{Gandom Beryan Hill}

This hill is located in 80 kilometers of north of Shahdad, it extends over an area of about 200 square kilometers; the local people also call this area Rig Soukhteh. The surface of the hill is covered with black volcanic lava. The existence of yellow soil around the mountain foot near the black basaltic rocks has turned this place into one of the beautiful attractions of Dasht-e Lut. During summer the temperature of the area varies from 65 degrees Celsius, in the shade, to about 100 degrees Celsius on volcanic rocks, due to their black color, they tended to absorb more sun's energy (Figure 17).

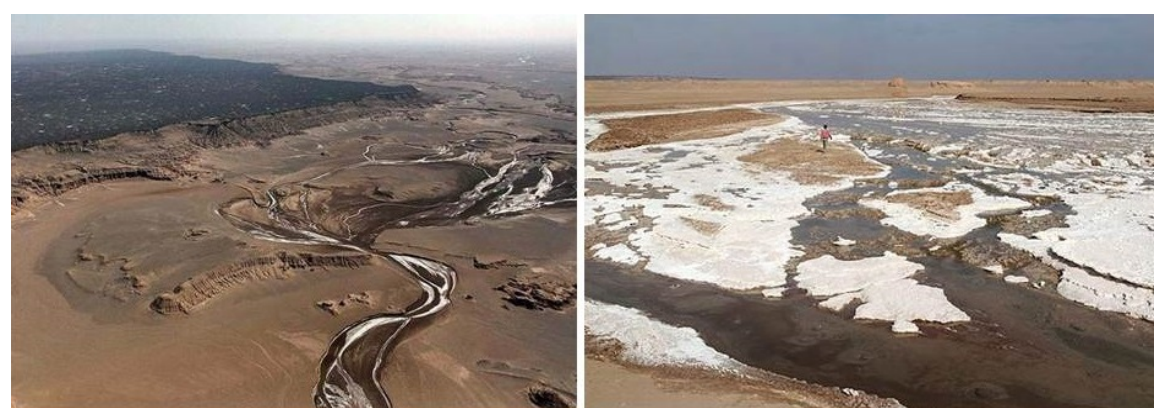

Figure 14. Rood-e shoor (Shoor River) in Dasht-e Lut.

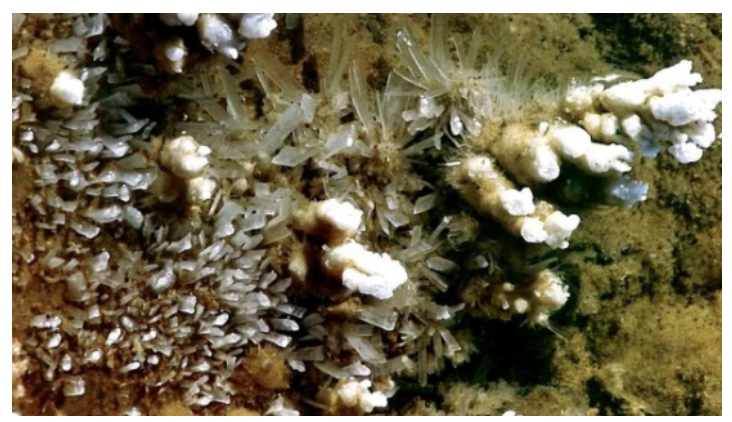

Figure 15. The beautiful crystals of gypsum in lut desert. 
In the Gandom Beryan area, the extreme conditions do not allow the existence of any animals or plants. Based on the performed research in the area, the corpses of livestock which were left in the area by passing trucks did not decompose; they were only dried due to extreme heat. Some people say that there are even no bacteria in this area, but recently two unknown insects-probably belonging to the spider species-were found, which are currently being studied by researchers.

The highest points of this hill are located in its east, 437 meters high, and in its northwest, 483 meters above the sea level.

there are numerous beautiful geomorphological phenomena in Dasht-e Lut, including forty quaternary volcano craters (Figure 18), vast areas of sand and pebble_called Godar-e Baroute-changing in color from light brown to gray and black, wavy areas of sand and ripple marks, salt polygons, beautiful scenes of mud cracks, etc.

Another one of Lut's notable wonders is the remnants of a civilization dating back to 3000 B.C. Archaeological excavations in the south of Shahdad found pottery and bronze objects in an old residential area which extended several kilometers in length and width; all of this points to the existence of an ancient city with a civilization with thousands of years' background.

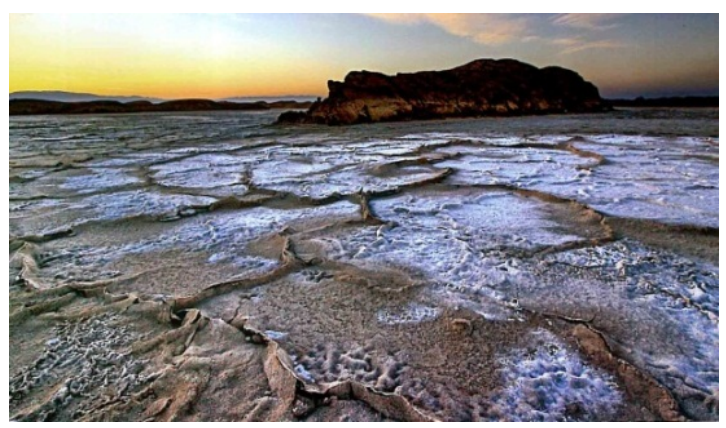

Figure 16. Rare scenery along rood-e shoor (shoor river).

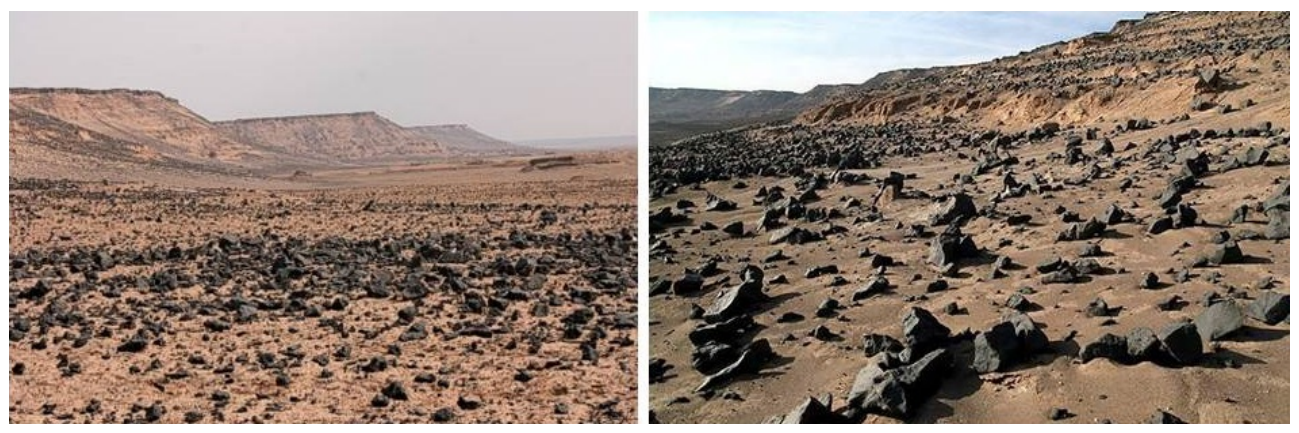

Figure 17. Gandom Beryan hill.

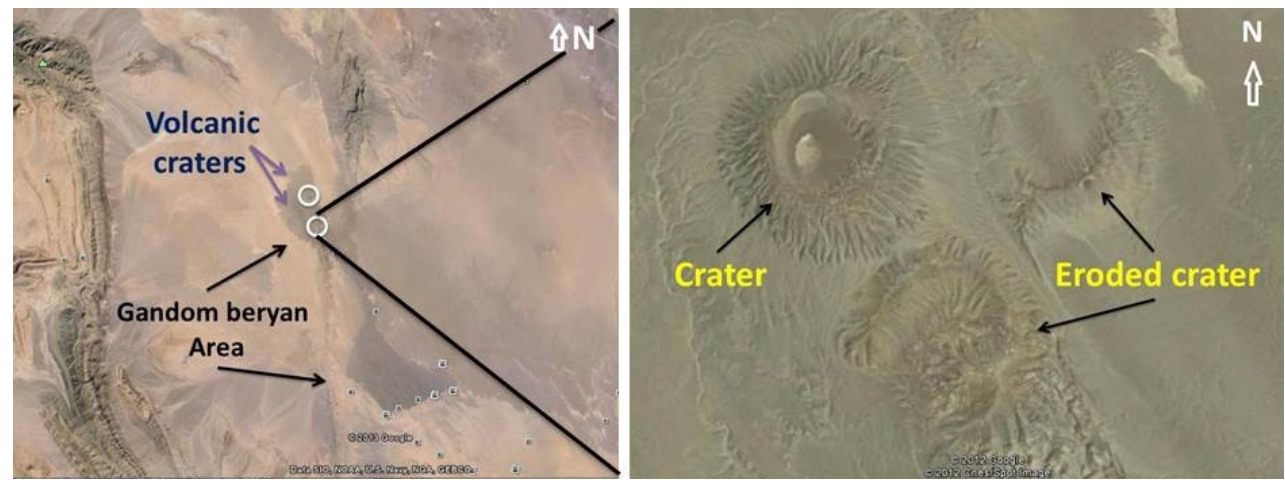

Figure 18. Volcanic crater in Gandom Beryan area. 


\section{Solutions to Geotourism Development in Dasht-e Lut}

\subsection{Develop and Build Ways for Access to Lut Desert's Attractions}

Roads are one of the most important infrastructures of tourism development in each region. Unfortunately, the only entrance to this region is Shahdad-Kaluts asphalted road, that after passing the area of Kaluts, this road continues as a dirt road through Nehbandan County. Obviously, this road is not sufficient for access to the attractions of a vast desert like Lut. By building new paths, the possibility of control and management of this area would be provided, that will be one of the most important solutions to developing geotourism industry in this region.

\subsection{Build Geotourism Development Centers in Provinces Bounded by Lut Desert}

Since Lut Desert locates between Kerman, Sistan and Baluchestan, and South Khorasan Provinces, some geotourism development centers can be built in each of these provinces. In case of establishing such centers, with a deliberate planning, the way can be paved for interpreting geotourism regions of Lut Desert, education and training of geotourism guides, preparation of signposts and so on, which in turn having considerable effect on development of this industry.

\subsection{Presentation of Wonderful Attractions of Lut Desert to Tourists from Other Countries through Advertisement}

By erecting geotourism development centers, with cooperation of such organizations as the Cultural Heritage and Tourism Organization, the Geology Organization and..., this region can be presented and thus attracting Iranian and foreign tourists. Given the fact that in many countries, there are no arid regions and desert landforms, through presentation and advertisement development, geotourists can be encouraged to visit the relieves of Iranian deserts, that is a factor affecting geotourism development.

\subsection{Dispatch Guides with Geotourists to the Region}

Since Lut Desert is a broad and arid plain with its own risks, it is recommended that, along with tourists, some trained individuals are dispatched so that geotourists can visit the attractions with a more correct planning without any concern. These guides must be fluent in English and familiar with the geographical, geological and topographical situation of the region, the roads, location of water fountains, natural attractions of Lut Desert and distance between them, astronomy and stars' situation in different seasons, as well as familiar with various animals, reptiles, insects, and treatment of their bites.

\subsection{Fight Bandits and Promote Security of Lut Desert}

Since Lut Desert was the place for passing some smugglers and bandits in the past years, the police have taken considerable actions to promote security of this region. However, for full security of tourists and promoting security of the region, the police should accompany them for their peace of mind. Obviously, this will increase eager of the enthusiasts to visit and develop geotourism.

\subsection{Erection of Accommodations for Tourists}

The only accommodations in Lut Desert are desert camps which are made of natural materials and built in the proximity of Kaluts. Given the economy of building such accommodations, building such camps in the other regions of Lut Desert will considerably influence geotourism development of this area.

Finally, deserts of Iran and in particular Lut desert (Dasht-e-Lut) include a wide number of geological and geomorphological phenomena that every visitors would like to see. Consequently, if more attention is paid to Dasht-e Lut, it can be turned into the most important tourist attraction for those interested in the desert, and it can help the country's economy.

\section{Conclusion}

The block of Lut is the huge desert in Iran, which is located between two faults: Nehbandan and Nayband. Due 
to a number of reasons, the special geological structure of this area, the 120-day winds blowing from Sistan and erosion associated with it. Various wonderful morphological phenomena were created in this area, including enormous sand pyramids, huge and wonderful Kaluts, the largest Nebkhas, beautiful salt lands, mud cracks and all other wonderful geological phenomena. This desert has become one of the world's most famous deserts due to the mentioned features as well as the following items: being one of the hottest places on the earth and hosting civilization with thousands of years' background. The number of Dasht-e Lut's morphological features has turned it into a natural academy for geography and geology researchers and lovers. All of these points to the fact that Lut has great potentials, with regard to tourist attractions. Furthermore, due to a number of factors, including the existence of two natural impassable areas (Rig-e Yalan and Kaluts) in the east and west of Lut, considering the lack of vegetation and drinking water, extreme heat and vastness, it is impossible to visit all its parts. As a result, it is regarded as one of the world's most mysterious places. Therefore, due to the mentioned points, the dangers involved in visiting the area, and the particular excitement involved in desert, Dasht-e Lut is assumed as an adventurous unique desert. Therefore, the authors propose this area as an international Geopark to the responsible organizations. Also, Dasht-e-Lut is a place that has all exceptional geomorphologic structures of desert together in its region. It could be recommended as an international Geopark to UNESCO.

\section{Suggestions}

Considering all the geological and morphological attractions mentioned above, there are other exciting activities parallel to geotourism attractions of Dasht-e-Lut, which can be follow. The following is a list of recreational activities that could be done in Dasht-e-Lut:

-Using sand dunes for having fun, for example sliding.

-Enjoying the sunny weather and fresh atmosphere, especially for tourists who are interested in sunbathing.

-Walking and long-distance cycling in parts of the desert.

-Enjoying Dasht-e-Lut's sky: clean air, less moisture, tranquility, and observing astronomical constellations for astronomy researchers.

-Car Racing and car-related entertainment.

-Skiing on sand.

\section{Acknowledgements}

The authors thank all editors and referee for their invaluable contributions and comments that certainly helped to improve the quality of this study.

\section{References}

[1] Amrikazemi, A. and Mehrpooya, A. (2006) Geotourism Resources of Iran. In: Dowling, R.K. and Newsome, D., Eds., Geotourism, Burlington (Elsevier Butterworth-Heinemann), Oxford, 78-90.

[2] Amrikazemi, A. (2009) Atlas of Geopark \& Geotourism Resources of Iran, Tehran. Geological Survey of Iran Publication, Tehran, 22-23, 270-289.

[3] Newsome, D. and Dowling, R.K. (2006) The Scope and Nature of Geotourism. In: Dowling, R.K. and Newsome, D., Eds., Geotourism, Chapter One, Elsevier, Oxford, 3-25.

[4] Gates, A.E. (2006) Geotourism: A Perspective from the USA. In: Dowling, R.K. and Newsome, D., Eds., Geotourism, Chapter Nine, Elsevier, Oxford, 157-179. http://dx.doi.org/10.1016/B978-0-7506-6215-4.50017-8

[5] Stocklin, Y. (1973) Basic Geological Study of Central Lut, East of Iran. Report 22-F, Institute of Geology and Mining Publications, Tehran.

[6] Moatamed, A. (1973) Lut Hole Geological Issues. Journal of Geographical Reports. Tehran University, Tehran, 11.

[7] Rahnama, R.J. and Saheb, Z.B. (2010) Geomorphology and Geology of Southeast Iran. Islamic Azad University of Zahedan, Zahedan.

[8] Aghanabati, A. (2004) Geology of Iran. Geological Survey of Iran, Tehran, 65-68.

[9] Ibrahimzade A. (2009) Geographical Principles of Southeast Iran. University Press of Sistan and Baluchistan, Zahedan.

[10] Rounaghi, A. (2012) Kavir and Deserts of Iran. http://www.irandesert.com

[11] Nabavi, M. (1984) Introduction to the Geology of Iran. Tehran University Publications, Tehran.

[12] Yazdi, A. and Shafiee, S.M. (2012) Feasibility of Iran Deserts for Geotourism Development. Proceedings of the 16th 
Meeting of Iran Geology Association, Shiraz, September 2012.

[13] Khosravi, H. (1998) Principles of Iran Geomorphology. University of Sistan-and-Baluchistan Press, Zahedan.

[14] Rahnama, R.J. and Saheb, Z.B. (2011) A Description of Dasht-e Lut Geomorphology as a Natural Academy for Learning Geographical Sciences. Islamic Azad University of Najaf Abad, Najafabad, 1257-1266.

[15] Solouti, S. and Babaniavardi, M. (2011) Desert Tour in Iran. Iran Shenasi Publication, Tehran, 17-29.

[16] Kardavani, P. (1973) From Shahdad to Deh Salam. Journal of Geographical Reports, 13, 17-21.

[17] Kardavani, P. (2004) Tourist Attractions of Iran’s Deserts. Magazine of Culture, Tehran. 